\title{
Multisystem Inflammatory Syndrome in Adults (MIS-A) Associated with SARS-CoV-2 Infection in a Young Adult Case from Turkey
}

\author{
Türkiye'den Genç Erişkin Bir Olguda SARS-CoV-2 Enfeksiyonu ile Ilişkili \\ Erişkinde Multisistem Inflamatuvar Sendrom (MIS-E)
}

\author{
Sibel ALTUNISIK TOPLU $\odot$, Yasemin ERSOY $\odot$, Yasar BAYINDIR $\odot$, Talat KILIC $\odot$, Volkan BAYAZIT $\odot$
}

Ethics Committee Approval: Not applicible.

Conflict of interest: The authors declare that they have no conflict of interest.

Funding: None.

Informed Consent: Inform consent was taken.
Cite as: Altunisik Toplu S, Ersoy Y, Bayindir Y, Kilic T, Bayazit V. Multisystem inflammatory syndrome in adults (MIS-A) associated with SARS-CoV-2 infection in a young adult case from Turkey. Medeni Med J. 2021;36:180-4.

\begin{abstract}
Weeks and even months after recovering from the SARS-CoV-2 infection, clinically more severe cases are being reported, which are suggestive of COVID-19-related multisystemic inflammatory syndromes (MIS). Firstly on March 2020, this condition was reported to be COVID-19 related to children (MIS-C). Since June 2020, a syndrome similar to multisystem inflammatory syndrome in adults (MIS-A) came to be noticed in adults as well. We reported here a case of 24-year-old young woman who had gone to a hospital with abdominal pain and later developed a severe cough, followed by development of subconjunctival bleeding, pericardial effusion, pleural effusion, and intra-abdominal fluid that we deemed them to be acute multisystemic clinical symptoms, 47 days after she had undergone a COVID-19 infection of mild clinical severity. It should be kept in mind that a multisystemic inflammatory syndrome along with a delayed immune response during COVID-19 disease can be seen not only in children but also in young adults, and seemingly severe clinical and laboratory findings can improve by controlling the inflammatory process.
\end{abstract}

Keywords: COVID-19, Multisystemic Inflammatory Syndrome in Adults (MIS-A), abdominal ache, subconjunctival bleeding, pericardial effusion, pleural effusion

öz

SARS-CoV-2 enfeksiyonu geçirdikten haftalar hatta aylar sonra, COVID-19 ile ilişkili birden çok sistemi etkileyen enflamatuvar bir sendrom olarak düşünülen ve klinik olarak daha ağır vakalar bildirilmektedir. Bu durum ilk önce (Mart 2020) çocuklarda COVID-19 ile ilişsili (MIS-C) olarak bildirilmiştir. Haziran 2020'den beri benzer şekilde, erişkin olgularda multisistemik inflamatuvar sendrom (MIS-E) farkedilmiştir. Burada, hafif klinik şiddette COVID-19 enfeksiyonu geçirdikten 47 gün sonra karın ağrısı ile başvuran ve sonrasında şiddetli öksürük ve hemen arkasından gelişen subkonjonktival kanama, perikardiyal efüzyon, plevral efüzyon, batın içi mayi gibi multisistemik olarak değerlendirdiğimiz akut klinik bulguların görüldüğü 24 yaşında genç erişkin bir kadın olgu bildirdik. COVID-19 sürecinde gecikmiș immün yanıtla birlikte multisistemik enflamatuvar bir sendronumun yanlızca çocuklarda değil genç erişkinlerde de görülebileceği ve şiddetli görünen klinik ve laboratuvar bulguların, enflamatuvar sürecin kontrol edilmesi ile düzelebileceği akılda tutulmalıdır.

Anahtar kelimeler: COVID-19, Erişkinlerde Multisistemik Inflamatuvar Sendrom (MIS-E), karın ağrIsI, subkonjonktival kanama, perikardiyal efüzyon, plevral efüzyon
Received: 7 March 2021

Accepted: 24 April 2021

Online First: 18 June 2021

Corresponding Author: S. Altunisik Toplu

ORCID: 0000-0002-2915-4666 Inonu University Faculty of Medicine, Department of Infectious Diseases and Clinical Microbiology, Malatya, Turkey saltuntoplu@gmail.com

\section{ORCID: 0000-0001-5730-6682 \\ Y. Bayindir \\ ORCID: 0000-0003-3930-774X}

Y. Ersoy Inonu University Faculty of Medicine,

Department of Infectious Diseases and Clinical Microbiology, Malatya, Turkey

T. Kilic

ORCID: 0000-0001-8125-9062 Inonu University Faculty of Medicine, Department of Pulmonary Diseases, Malatya, Turkey

V. Bayazit

ORCID: 0000-0003-4128-1323 Inonu University Faculty of Medicine, Malatya, Turkey 


\section{INTRODUCTION}

Multisystemic Inflammatory Syndrome in Adults (MIS-A) is defined as a new condition that occurs after recovering from coronavirus infection 2019 (COVID-19). Centers for Disease Control and Prevention (CDC) brought together and published several adult case reports and series which have been recognized since June 2020 until now in The Morbidity and Mortality Weekly Report (MMWR) ${ }^{1}$. This new condition was reported first on March 2020 as a COVID-19 related MIS-C. Also, MIS-C was likened to Kawasaki disease $(\mathrm{KD})^{2-4}$. MIS-C was published as a new disease that has clinical features as shock, cardiac dysfunction, abdominal ache, and elevation of inflammatory markers, which are C-reactive protein (CRP), ferritin, D-dimer, and interleukin ${ }^{5}$. KD is extremely rare in adults. On the other hand, after SARS-CoV-2 infection, severe course of COVID-19 clinic is less common in young adults and children. This syndrome, which was defined primarily in children in the late period after recovering from SARS-CoV-2 infection, can be seen especially in young adults.

\section{CASE PRESENTATION}

A 24-year-old female patient without any known chronic disease presented with abdominal pain. It was learnt that the patient was diagnosed with COVID-19 infection 47 days ago but did not receive antiviral therapy. She tested for SARSCOV-2, but she had negative laboratory results for the disease. She was hospitalized after detection of 24 leukocytes/HPF in her complete urinalysis. On the second day of her hospitalization, severe headache and subconjunctival hemorrhage developed (Figure 1, the picture of the patient was shown with the approval of our patient) and also her body temperature was $38.9^{\circ} \mathrm{C}$. The patient had sinus tachycardia. She had recurrent episodes of high fever despite medical interventions. Increased blood leukocyte counts and progressive lymphopenia were observed in her laboratory results. There were some more changes in her laboratory values (Table 1). Pulmonary consolidation developed which had

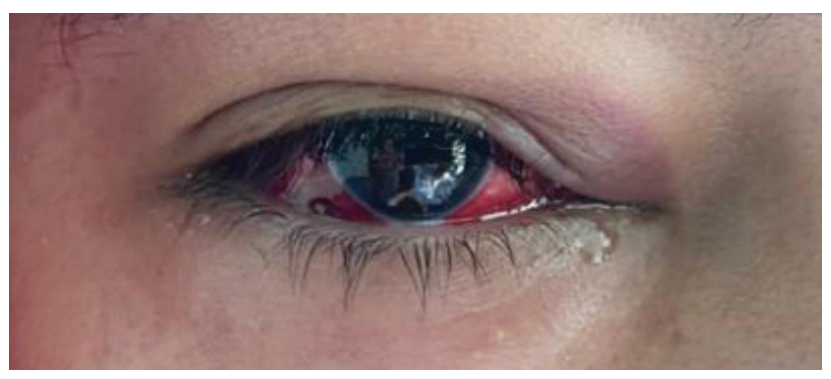

Figure 1. Image of subconjunctival hemorrhage.

Table 1. Changes in some laboratory values from the first day of hospitalization of the patient to discharge.

\begin{tabular}{|c|c|c|c|c|c|c|c|c|c|c|}
\hline HD & $\begin{array}{c}\text { WBC } \\
\left(10^{\left.\wedge^{3} / u L\right)}\right.\end{array}$ & $\begin{array}{c}\text { LY\# } \\
\left(10^{\wedge^{3}} / \mathrm{uL}\right)\end{array}$ & $\begin{array}{c}\text { Plt } \\
\left(10 \wedge^{3} / u L\right)\end{array}$ & $\begin{array}{c}\text { PCT } \\
(\mathrm{ng} / \mathrm{mL})\end{array}$ & $\begin{array}{c}\text { IL-6 } \\
(\mathrm{pg} / \mathrm{mL})\end{array}$ & $\begin{array}{c}\text { CRP } \\
(\mathrm{mg} / \mathrm{dL})\end{array}$ & $\begin{array}{l}\text { ProBNP } \\
(\mathrm{pg} / \mathrm{mL})\end{array}$ & $\begin{array}{c}\text { T-I } \\
(\mathrm{pg} / \mathrm{mL})\end{array}$ & $\begin{array}{l}\text { Albumin } \\
\text { (g/dL) }\end{array}$ & $\begin{array}{c}\text { LDH } \\
\text { IU/mL }\end{array}$ \\
\hline 0 & 12.8 & 1.1 & 198 & 0.39 & 47.16 & 5.22 & & 1.3 & & 260 \\
\hline 1 & 11.16 & 0.36 & & & & 10.1 & & & & 224 \\
\hline 2 & & & 97 & & & & & & & \\
\hline 3 & 13.5 & 0.440 & 92 & 2.03 & 1353 & 26.8 & & & 2.9 & 374 \\
\hline 4 & 21.22 & 0.52 & 110 & & & & 7795 & & 2.6 & 457 \\
\hline 5 & & 0.98 & 137 & & & & & & & \\
\hline 6 & 18.5 & 1.920 & 205 & & 17.57 & 9.14 & & & 2.3 & \\
\hline 7 & 21.7 & 2360 & & & & & & & & \\
\hline 8 & & & & 0.849 & & & 3364 & & & \\
\hline 9 & & & 302 & & & 3.51 & & & & \\
\hline 10 & 25.7 & 3620 & & & 5.62 & & 707 & & 2.7 & 308 \\
\hline 11 & & & 418 & & & & & & & \\
\hline 12 & 22.1 & 3270 & & & & & & & & \\
\hline 13 & & & 375 & 0.158 & 2.47 & $<0.314$ & 48 & & & \\
\hline $50^{\text {th }}$ day after discharge & 8.78 & 2350 & & & & & & & 4.8 & \\
\hline
\end{tabular}

HD: Hospitalization day, C-reactive protein (CRP): (0-0.351) $\mathrm{mg} / \mathrm{dL}$ (normal reference range), WBC: white blood cells, T-I: troponin-I, LY: lymphocytes, PCT: procalcitonin (0-0.5) ng/mL (normal reference range), interleukin-6 (IL-6): (0-7) pg/mL (normal reference range), ProBNP: ProB-type natriuretic peptide, $L D H$ : lactate dehydrogenase. 
not been seen three days ago. Changes in the patient's lung imaging within three days are shown in Figures 2, and 3. Scanning showed that the main pulmonary artery and its branches were free of embolism. Bilateral pleural effusion and 5 $\mathrm{cm}$ deep free fluid between intestinal loops in abdominal ultrasound imaging were reported as pathological results. On the third day of hospitalization, the antibacterial treatment with meropenem, linezolid, and clarithromycin was rearranged and ordered. Repetitive Polymerase Chain Reaction (PCR) tests for SARS- CoV-2

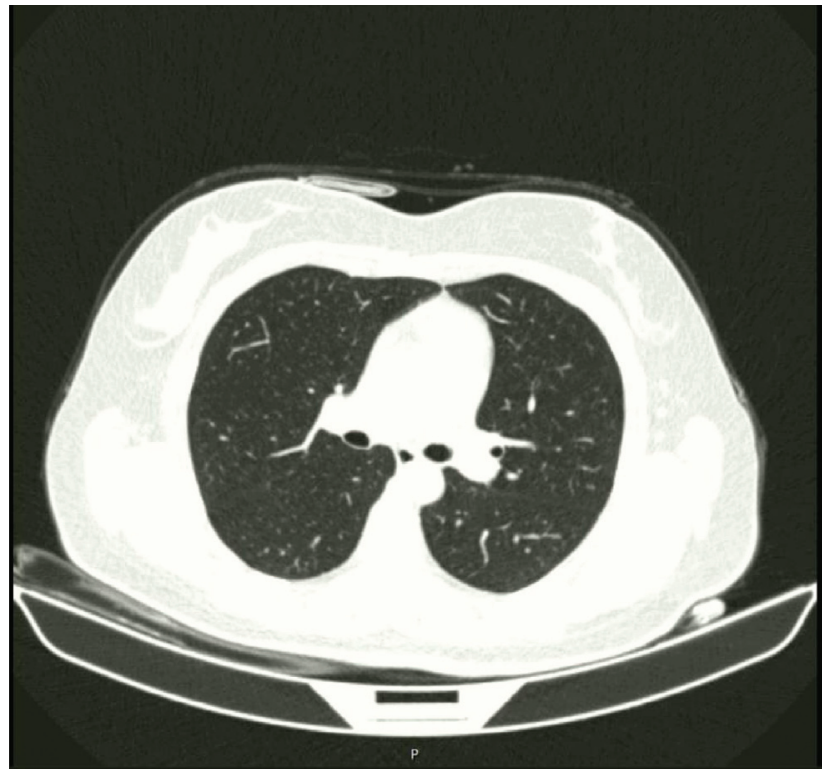

Figure 2. Toraks ct of first hospitalization day.

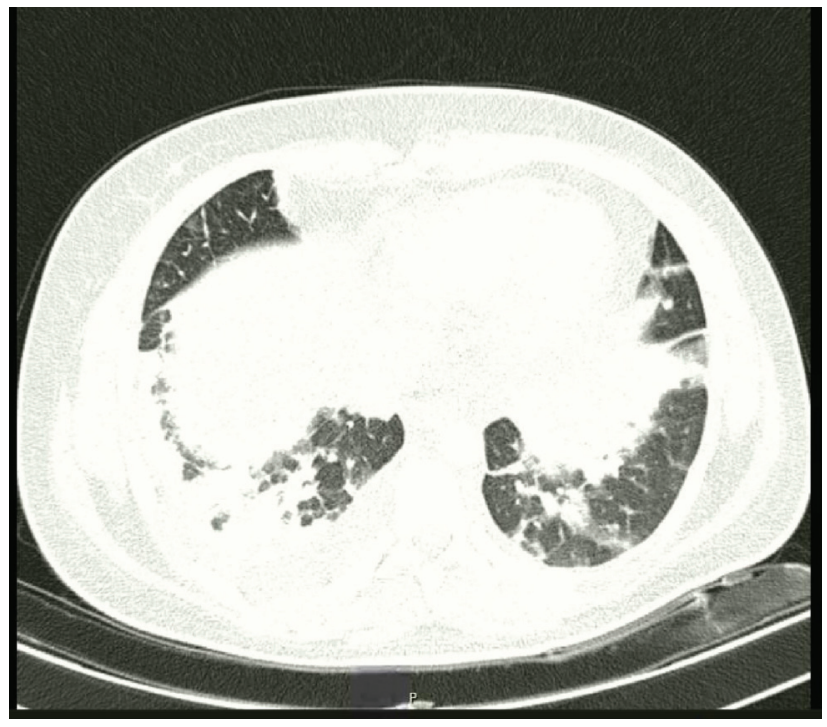

Figure 3. Toraks ct of third hospitalization day. yielded PCR-negative results. Ferritin level was $1424 \mathrm{ng} / \mathrm{mL}$ and D-dimer level $16.74 \mathrm{mg} / \mathrm{L}$. On the fourth day of hospitalization, $40 \mathrm{mg}$ prednisolone was started. After steroid treatment, the patient's fever did not elevate again. Patient's COVID-19 (SARS- CoV-2) IgG value was measured as 3.19 (Abbott ARCHITECT SARS-CoV-2 IgG Instructions for Use, index 0-1.4) and IgM value as 1 (Abbott ARCHITECT SARS-CoV-2 IgM Instructions for Use, index 0-1). Pericardial effusion was shown in echocardiography. Sinus tachycardia was thought because of the heart rates occasionally reaching $150 \mathrm{bpm}$. Cardiac ejection fraction measured $60 \%$ (>53\% normal). On the sixth day of hospitalization, ibuprofen (3x600 mg tablet) and colchicine $(2 \times 0.5 \mathrm{mg}$ tablet) were ordered. There was no growth in urine culture. The levels of acute phase reactants including C-reactive protein (CRP), procalcitonin (PCT), and interleukin-6 (IL-6) were normalized on the seventh day of hospitalization due to steroid treatment (Table 1). Antibiotic treatment was stopped when the patient started feeling fine clinically. On the 13th day of hospitalization, the patient was discharged. Patient was using $32 \mathrm{mg}$ steroid at the time of discharge. Her steroid dose tapered by $8 \mathrm{mg}$, and finally stopped. Treatment with ibuprofen tablet and colchicine continued for 10 days. Patient's blood chemistry results were within normal limits 50 days after her discharge. The patient's consent was obtained for the publication of this case report.

\section{DISCUSSION}

MIS-A is a newly perceived hyperinflammatory response disease that occurs after COVID-19 infection. On the other hand, a case definition was made for MIS-C seen in pediatric cases. The age range of the patients is between 0 and 21 years. Other diagnostic criteria were as follows: body temperature $>38.0^{\circ} \mathrm{C}$ lasting more than 24 hours or family reporting the presence of fever; evidence of inflammation in laboratory tests (presence of at least two or more of the following 
laboratory criteria: increased CRP, PCT, D-dimer, IL-6, LDH levels, lymphopenia, and hypoalbuminemia), presenmce of a severe disease requiring hospitalization and multi-organ system involvement [the presence of at least two or more abnormal cardiovascular (e.g., shock, high troponin, high BNP, abnormal echo symptoms, and arrhythmia), respiratory (pneumonia, ARDS, and pulmonary embolism), renal (renal failure), neurological (convulsion, stroke, aseptic meningitis), hematological (coagulopathy, high D-dimer level), gastrointestinal (high liver enzymes, diarrhea and ileus), and dermatological findings (erythroderma, mucositis, and another rash), lack of any other alternative diagnosis (such as bacterial sepsis, myocarditis-related infections such as enterovirus infection, staphylococcal or streptococcal toxic shock syndromes), and evidence of past or recent SARS-CoV-2 infection (SARS-CoV-2 RT-PCR- positivity, SARS-CoV-2 serology positivity, SARS-CoV-2 antigen positivity, contact with an at least one SARS-CoV-2 positive case) $]^{6}$. Our case was 24 years old but fulfilled most of the other criteria.

The pathological relation between MIS-C/MIS-A and SARS-CoV-2 has not been enlightened yet ${ }^{5}$. There is a report of a young adult woman from Belgium that indicated that this syndrome is a late immunity reaction against COVID-19 and the viral molecule cannot be demonstrated by molecular analyzes ${ }^{7}$. In our case, the patient's nasopharyngeal swab for SARS-CoV-2 came positive 47 days ago, but the disease was mild, and she did not use antiviral treatment. SARSCoV-2 PCR tests of the patient who applied to the emergency service with abdominal pain and high fever two days after her admission, yielded negative results. Afterwards, subconjunctival hemorrhage, pleural and pericardial effusion, presence of free abdominal fluid, edema on the eyelid, clinical and radiological imaging made us think about hyperinflammatory reactions. Patient's COVID-19 (SARS-CoV-2) IgG level was detected as 3.19 and (index 0-1.4) IgM level as 1 (index
0-1). Detection of SARS-CoV-2 specific antibodies supported our opinion.

Acute COVID-19 disease is related to hyperinflammatory disease; however, the late multisystemic inflammatory syndrome is different from acute COVID-19 hyperinflammation ${ }^{5}$. There are laboratory results suggesting hyperinflammation, without any evidence of shortness of breath. Besides that, extrapulmonary organ dysfunction could be severe. Cardiac symptoms, which include left ventricular heart failure, high troponin levels, but most commonly arrhythmias were reported ${ }^{1}$. In our case, rapidly elevated IL-6, PCT, CRP, ferritin, P-BNP, D-Dimer levels and pleural effusion, pericardial effusion, tachycardia (up to $150 / \mathrm{bpm}$ ), and shortness of breath were seen in the first two days. On the fourth day of hospitalization, patient's Pro-BNP (NT-proBNP) level was 7795 pg/ $\mathrm{mL}$ (normal: 0-110 pg/mL). Increased brain natriuretic peptide (BNP) and ProB-type natriuretic peptide(NT-proBNP) levels have been demonstrated in cases with heart failure ${ }^{8}$. However, ejection fraction was $60 \%$ (normal: > 53\%) on echocardiogram on the fifth day of hospitalization.

Intravenous immunoglobulin, corticosteroids, IL-6 receptor inhibitor tocilizumab, and various antibiotherapies had been administered to the patients with MIS-A. Most of the patients recovered even they had clinically severe symptoms ${ }^{1}$. In a 25 -year-old case reported from Atlanta (USA), the patient had recovered after treatment with intravenous immunoglobulin (IVIG), aspirin, and supportive care?. Clinical condition of our patient improved one day after she took steroid treatment. Her body temperature became normal. Due to cardiac findings, ibuprofen and colchicine were added to her prescription on the sixth day of hospitalization. Bacteria culture tests did not reveal any evidence supporting the presence of an infection. The patient was clinically recovered after seven days of steroid treatment. Laboratory tests were all within normal limits $\mathbf{5 0}$ days after her discharge. 


\section{CONCLUSION}

The case definition for MIS-C was made by the Centers for Disease Control and Prevention (CDC) ${ }^{6}$. Similar clinical features can be seen in cases reported in adults; however, there have been a limited number of cases reported as MIS-A so far $^{1,6,9}$. Clinicians should consider MIS-A in adults with coherent signs and symptoms of COVID-19. It is helpful to recognize and treat cases of MIS-A, based on mainly clinical suspicion and antibody testing for SARS-CoV-2. More data are needed to understand better the pathogenesis, risk factors, clinical-laboratory variables, and results of this newly described condition in order to guide the treatment.

\section{REFERENCES}

1. Morris SB, Schwartz NG, Patel P, et al. Case series of multisystem inflammatory syndrome in adults associated with SARS-CoV-2 infection - United Kingdom and United States, March-August 2020. MMWR Morb Mortal Wkly Rep. 2020;69:1450-6. [CrossRef]

2. Feldstein LR, Rose EB, Horwitz SM, et al. Multisystem inflammatory syndrome in U.S. children and adolescents. N Engl J Med. 2020;383:334-46. [CrossRef]

3. Mamishi S, Movahedi Z, Mohammadi $M$, et al.
Multisystem inflammatory syndrome associated with SARS-CoV-2 infection in 45 children: a first report from Iran. Epidemiol Infect. 2020;148:e196. [CrossRef]

4. Dove ML, Jaggi $P$, Kelleman $M$, et al. Multisystem inflammatory syndrome in children: survey of protocols for early hospital evaluation and management. J Pediatr. 2021;229:33-40. [CrossRef]

5. Weatherhead JE, Clark E, Vogel TP, Atmar RL, Kulkarni PA. Inflammatory syndromes associated with SARSCoV-2 Infection: dysregulation of the immune response across the age spectrum. J Clin Invest. 2020;130:6194-7. [CrossRef]

6. Center for Disease Control and Prevention, Center for Preparedness and Response [Internet]. Multisystem Inflammatory Syndrome in Children (MIS-C) Associated with Coronavirus Disease 2019 (COVID-19), Clinician Outreach and Communication (COCA) Webinar. Available from: https://emergency.cdc.gov/coca/calls/2020/ callinfo_051920.asp

7. Cogan E, Foulon P, Cappeliez O, Dolle N, Vanfraechem G, De Backer D. Multisystem inflammatory syndrome with complete Kawasaki disease features associated with SARS-CoV-2 infection in a young adult. A Case Report. Front Med (Lausanne). 2020;7:428. [CrossRef]

8. Luchner A, Hengstenberg C, Löwel H, Riegger Günter AJ, Schunkert H, Holmer S. Effect of compensated renal dysfunction on approved heart failure markers: direct comparison of brain natriuretic peptide (BNP) and N-terminal pro-BNP. Hypertension. 2005;46:118-23. [CrossRef]

9. Kofman AD, Sizemore EK, Detelich JF, Albrecht B, Piantadosi AL. A young adult with COVID-19 and multisystem inflammatory syndrome in children (MIS-C)like illness: a case report. BMC Infect Dis. 2020;20:716. [CrossRef] 